\title{
Designing a tool to analyse the performance of biological systems
}

The case of evaluating soft wheat cultivars

Lorène Prost, Christophe Lecomte, Jean-Marc Meynard and Marianne

Cerf

\section{CpenEdition}

\section{Journals}

Electronic version

URL: http://journals.openedition.org/activites/1693

DOI: 10.4000/activites.1693

ISSN: $1765-2723$

\section{Publisher}

ARPACT - Association Recherches et Pratiques sur les ACTivités

\section{Electronic reference}

Lorène Prost, Christophe Lecomte, Jean-Marc Meynard and Marianne Cerf, « Designing a tool to analyse the performance of biological systems », Activités [Online], 4-2 I octobre 2007, Online since 15 October 2007, connection on 30 April 2019. URL : http://journals.openedition.org/activites/1693 ; DOI : 10.4000/activites. 1693

\section{c) $(1) \Theta$}

Activités est mis à disposition selon les termes de la licence Creative Commons Attribution - Pas d'Utilisation Commerciale - Pas de Modification 4.0 International. 


\title{
Designing a tool to analyse the performance of biological systems: The case of evaluating soft wheat cultivars
}

\author{
Lorène Prost \\ INRA, UMR INRA-AgroParisTech Agronomie, BP1, F-78850 Thiverval Grignon, prost@grignon.inra.fr
}

\section{Christophe Lecomte}

INRA, UMRLEG, 17 Rue Sully, BP 86510, F-21065 Dijon cedex , lecomte@epoisses.inra.fr

\section{Jean-Marc Meynard}

INRA, Département SAD, BP1, F-78850 Thiverval Grignon, meynard@grignon.inra.fr

\section{Marianne Cerf}

INRA, UMR INRA-AgroParisTech, SAD-APT, BP1, F-78850 Thiverval Grignon, cerf@agroparistech.fr, correspondant.

\begin{abstract}
New cultivars have always been a key element in the development of cropping systems. The assessment of new cultivar performance in a diverse range of environments (soil, climate, production methods) is a key issue for the actors along the chain which links breeders to growers and food suppliers. As agronomists and ergonomists, we worked together to design a tool aimed at supporting these actors in assessing cultivar performance in order to link three aspects of the design process: (i) the crystallisation in the tool of an activity model, (ii) the flexibility of the tool, (iii) the joint development of the tool and the activity. To produce specifications based on these aspects, we analysed respectively (i) the invariants of the activity system of cultivar assessment, (ii) the diversity of actions performed by actors involved in cultivar assessment, (iii) the contradictions which arise within the activity system. Our analysis calls on existing historical studies but is based mainly on interviews with 21 people involved in cultivar assessment and gave us an insight into the actions of assessment activity. This analysis enables us to point out that the network of field trials is a key tool for the activity of cultivar assessment and to study how actors take advantage of the vagueness of the various tools to transform them into instruments. It also shows that, historically, the object of the activity has been built around assessing the stability of cultivar performance and that stability still gives direction to the actions undertaken by actors today. Eleven different actions for evaluating cultivars were identified. Our analysis highlights the contradictions which emerge today within the object of the activity system due to the new issues that actors have to face. It led us to define specifications for a prototype tool which is flexible enough to adapt to the diversity of actions and which could be used to enable actors to overcome some of the contradictions identified.
\end{abstract}

KEYWORDS

Tool design, activity system, agriculture, instrument 


\section{1.- Introduction}

In agriculture, breeding the best plants has always been regarded as an important lever for controlling production and solving agronomic problems. Today this has led to dozens of new cultivars of the most widely grown species being put on the market every year. This is the case with soft wheat, which is the focus of our study.

In order to be grown in France, a cultivar must be registered in an official catalogue, which means it must first be evaluated and codified by the Technical Breeding Permanent Committee (CTPS). Although this evaluation period is formative and essential for all the actors, it is preceded and followed by numerous other evaluations. During their life cycle, cultivars are first of all created by a breeder, then followed up by "developers" to identify potential growing locations and markets. During roughly the same period the new cultivars undergo the registration tests that will enable them to appear in the official catalogue. Next they are multiplied by multiplication-distribution organisations, which offer them for sale. Then they are grown and harvested by farmers. The majority of the harvest is collected by cooperatives, which make up batches of pure cultivars and mixtures of several cultivars for processing by agro-industrial companies, mainly for animal or human food. At each stage in the process, the cultivars are evaluated at national, regional and local level, depending on the scope of the actors' work. So the "cultivar industry" involves not only a large number of actors, but also close coordination between the actors and their activities: cultivar assessment is handed on several times from the breeding to the transformation stage.

Most of these actors have developed their own evaluation procedures to pinpoint which cultivars comply best with their requirements. Nonetheless, they say they are not satisfied with the procedures they are using today (Cerf, \& Hochereau, 2004) because those procedures do not seem appropriate to current developments. The first of these is the shorter life of a cultivar on the markets, which has gone from ten years in 1970 to four years today (Campariol, 1992; Lecomte, 2005). That means the actors have less time to learn how the cultivars perform in different environments (i.e. soil, climate, production methods). The second development (Meynard, \& Jeuffroy, 2006) is related to the greater diversity of expectations regarding the technical performance of cultivars (such as different specifications for different kinds of bread) and an increase in the range of technical procedures used depending on the performance required (from high-input systems to integrated cropping systems and organic farming, which use little or no chemical inputs). It then becomes vital to acquire a better understanding of how a particular cultivar can perform in a range of enviroments or in a very specific environment.

Pooling procedures for acquiring information and sharing that information could be one of the ways in which actors could increase the effectiveness of evaluation and reduce the time needed to assess cultivar performance, but it is difficult to put into practice because of the competition between actors in the "cultivar industry". Information about cultivars, notably their performance in a range of environments, is strategically important because it allows those cultivars to be slotted into a competitive market. Since such cooperation is lacking, each actor has to build up the necessary resources to study cultivar performance in a range of environments. In practical terms, this means networks of cultivar trials must be set up.

Cultivar trials involve comparing the results obtained with different cultivars in field trials, "all other factors being equal". No fixed number of cultivars is tested in each trial because this depends on the individual actors. The trials are repeated in a range of different environments to evaluate cultivar performance faced with various environmental constraints and to allow for a characteristic intrinsic to all living things: they adapt to suit their surroundings. The trials as a whole constitute what those involved in the evaluation process call a cultivar trials network, involving trials all over the area covered by the actors (the size of a département for some, the whole of France for others) over one or more years. To give a practical example, the GEVES, which conducts trials with a view to registering cultivars in the official catalogue, has a cultivar trials network covering more than 40 sites throughout France where trials are conducted over a two-year period. But such networks are expensive. The cost 
of the network could be even higher if the actors wanted to incorporate the increasing diversity of technical procedures used and performance sought.

Agronomists have suggested describing the effective diversity of environments in a network by highlighting "limiting factors". These are factors which prevent a particular level of performance - such as a cultivar's yield in metric tons of grain per hectare - from being reached. These limiting factors (e.g. shortage of nitrogen, water stress, frost, diseases) vary greatly from one plot to another and from one year to the next. The effect they have depends on the degree of development of the plant and its resistance to them. Although the resistance will depend on the state of the plant when the factor appears and the subsequent possibility of compensation, it is determined first and foremost by genetics. It is a matter of using to best advantage the interactions that arise between a cultivar and its environment, including all the limiting factors. These interactions are complex, and analysing them requires both the relevant observations and the appropriate statistical tools to be available.

Several tools to help interpret the interaction between cultivars and environments have been put forward by researchers - both agronomists and statisticians - but very few have been taken up by the actors performing an evaluation. That is why we decided to design a new tool based on an analysis of the activity of evaluating cultivars. This paper presents the approach adopted to produce specifications for the tool, as well as the understanding it gave us about the activity itself.

\section{2.- A design approach linking crystallisation, flexibility and development}

There is nothing original in ergonomics about planning to design a tool by analysing the situations in which it might be used, but it is always appropriate to reflect on how such an analysis should be conducted and how it might be expressed as a set of specifications. We chose to regard the task of evaluation on the scale of the cultivar industry as an activity system as defined by Engeström (1987) and to focus in particular on the level of evaluation actions: that on which the activity is carried out in the industry, and the various occupations involved. It is important to remember that Leont'ev (1977) distinguishes between the levels of activity, action and operation in describing how human activity is organised. In fact activity, driven by a "motive", is built up over a long period from shorter-term procedures known as actions, which are driven by more specific goals, themselves broken down into operations which are subject to conditions (Kuutti, 1995). Positioning ourselves on the level of actions gives us access to what constitutes the activity of evaluation and a means of observing it. We have two aims in observing actions. Firstly, on this level, we want to understand and structure the diversity of actions in the activity system, and to appreciate how it restricts the dynamics of the activity system. This will provide us with useful information about the tool to be designed so that it responds effectively to the diversity of evaluation actions. Secondly, we want to understand the instrumental dimension of the actions that contribute to the activity of evaluation. We are advancing the hypothesis that at this level it is possible to understand the procedures of instrumentation and instrumentalisation put forward by Rabardel (1995), to appreciate the transformation of artefacts into instruments with their twin dimensions: objective and subjective, material and human. It is the way that the actors use the tools available for evaluating cultivars and achieving their own objectives regarding evaluation which transforms those tools into instruments. It is necessary for us to understand the instrumental dimension because designing a tool also means enabling actors to include it in the range of instruments already available and probably causing a transformation of the instrumental dimension of their actions.

We chose this approach to activity because we wanted to link three aspects right from the start of the design stage, as suggested by Béguin (2007): (1) crystallisation in the tool of a model of the activity, with any artefact including a model of the user and of their activity; (2) flexiblity of the tool, which should provide users with room to manoeuvre so that they can cope with any variations in the situa- 
tion - something that can never be completely covered by the tool; (3) joint development of the tool and the activity in so far as it is the appropriation of the tool and its conversion into an instrument which completes the design process.

The crystallisation of a model of the user and of his/her activity is based on bringing to the fore relatively stable forms of action, over and above the use of general criteria about how humans function. In order to do this, we shall endeavour to identify the characteristics shared by the actions carried out by the various occupations in the cultivar industry and to understand the systemic dimension of the activity of evaluation.

In order to tackle the flexibility of the tool, we decided to analyse the range of evaluation actions and not to look at the range of operations. In other words, it is not so much the variability that each actor encounters in carrying out actions which forms the core of our analysis. It is more the variability of methods observed between actors carrying evaluation actions. This was a pragmatic decision: it seems to us that the activity of evaluation can be split into different forms of action throughout the industry. Defining this first level of diversity is both the preliminary stage of a more detailed analysis and the guarantee that the future tool is suitable for this level of diversity. This decision then enabled us to define how two forms of mediation could be provided for the actors in their individual circumstances: mediation by the tools on the one hand and by work rules and organisation on the other. One of the challenges of the analysis is to suggest a way to organise this diversity that highlights specifications regarding the flexibility sought for the tool. It is not a question here of assuming a priori that the various occupations responsible for evaluating cultivars in the industry necessarily have different ways of carrying out their actions. Being able to pinpoint which differences «count» means we have to try to clarify what factors may be used to classify the various occupations into groups.

The development issue is a more sensitive one. In the absence of any prototype, it is difficult to follow the suggestion made by Béguin (2005) that the proximal development zone of future users should be manipulated by simulation using a prototype. At the moment, the tool is still only at the design stage and the challenge facing us is to define the characteristics of the prototype. Nonetheless, if we want the prototype to play this role in future, what properties should we give to it? Manipulating the proximal development zone of future users does not only mean enabling them to appropriate a new tool and make it an instrument of their action: it also means providing them with the resources to take a more comprehensive view of the development of their activity. Could the tool, under certain conditions, generate a «mirror effect», leading future users to take such a view and thereby contributing to the development of the activity system? Engeström (1987) suggests as a «mirror» a representation of the activity system which brings out the contradictions in the system. It is the fact of bringing out the contradictions which seems to be key. Miettinen (2006) demonstrates that introducing a new tool can also play the role of revealing the contradictions in an activity system. We have therefore tried to design a prototype that will reveal to the actors certain contradictions (which we will endeavour to pinpoint) between the way the activity is carried out today and the new issues which actors in the cultivar industry would like to incorporate.

So specifications for the tool must be devised with each of these three aspects in mind: crystallisation, flexibility and development. In practical terms, it is a case of producing specifications for the tool based on, on the one hand, the elements that make up the activity system of evaluation and, on the other, the diversity observed on the level of actions, and also of enabling the contradictions that must be overcome to be highlighted by the tool.

\section{3.- List of data about evaluation actions}

\section{1.-Choosing the actors}

To carry out our analysis, we met 21 people involved in evaluation actions from all parts of the cul- 
tivar industry (Table 1).

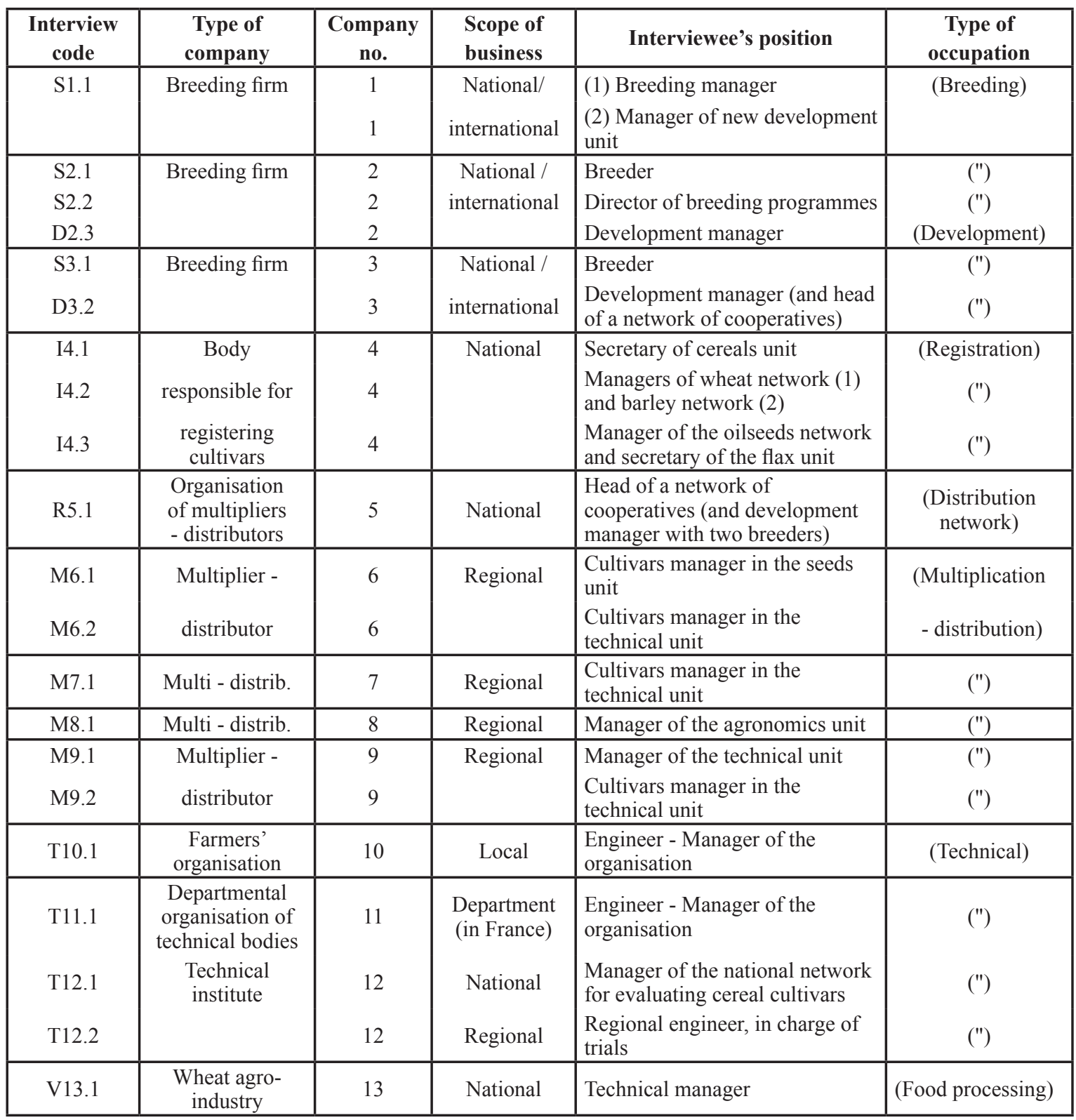

Table 1: Companies surveyed and interview codes.

The people surveyed were selected firstly by occupation (breeding, multiplication, marketing, development), a criterion which is a priori more important than the type of organisation they belong to (private or public breeder, multiplier, development organisation...). They were chosen initially from people whose names were known within the various occupations. From this starting point, the scope of the survey was expanded using the so-called "snowball method" (Blanchet, \& Gotman, 1992, p.58), with one interviewee supplying contact details for another after being asked: "Could you put us in touch with someone who in your view carries out the job of evaluation very differently from yourself?" This ensured that the differences between those interviewed were as great as possible and enabled us to investigate the widest possible diversity in terms of evaluation actions. The procedure came to an end when the most recent interview no longer provided information that was significantly original compared to all the previous interviews.

Our investigations focused on evaluation actions for cultivars of soft wheat, the kind most commonly grown in France, and a matter of interest to all the people surveyed. 


\section{2.- Observing evaluation or conducting interviews and analysing data about the activity?}

It is difficult to observe the job of evaluation in progress, both for confidentiality reasons (the resulting information about a cultivar is of strategic importance) and because of the time-frame involved: the work is concentrated into a period of a few weeks during which the person involved is under pressure and is not readily available to explain what he or she is doing. For these reasons, we focused on semi-directed interviews (Blanchet, \& Gotman, 1992) and on discussing the written data produced by the actors in the course of their work: draft data lists, notebooks, trial reports, analysis charts.

Whenever possible, the interviews were conducted with two interviewees: (a) the person in charge of the procedure of assessing cultivars and (b) the person who summarised and interpreted the results of cultivar trials and reported their findings to the first person. With both present, we were able to appreciate simultaneously the goals of the evaluation procedure and the criteria used to carry it out, to understand on the one hand how data supplied by the investigative and data analysis tools for cultivar peformance are used, and on the other how the data are put together and how the tools in question are used. The interviews were conducted by a researcher who was also personally involved in evaluating cultivars, which can be a plus factor but may also lead to implicit opinions about the work of the interviewee. The interview technique adopted sought to restrict this danger. It was based on five major open questions (see Appendix 1) asked by the interviewer, who only intervened subsequently to clarify points made by the interviewee, summarising what the interviewee said and then asking if the summary was relevant and correct. ("If I understood correctly" or "If I may summarise that, you just said (...) Is that right?").

\section{3.-Analysing the data}

All the interviews were transcribed, then summarised in tables. The lines correspond to individual interviewees. The columns correspond to the indicators we decided were relevant in describing the objects and instruments of the evaluation action (see also the list of indicators selected in Figure 1).

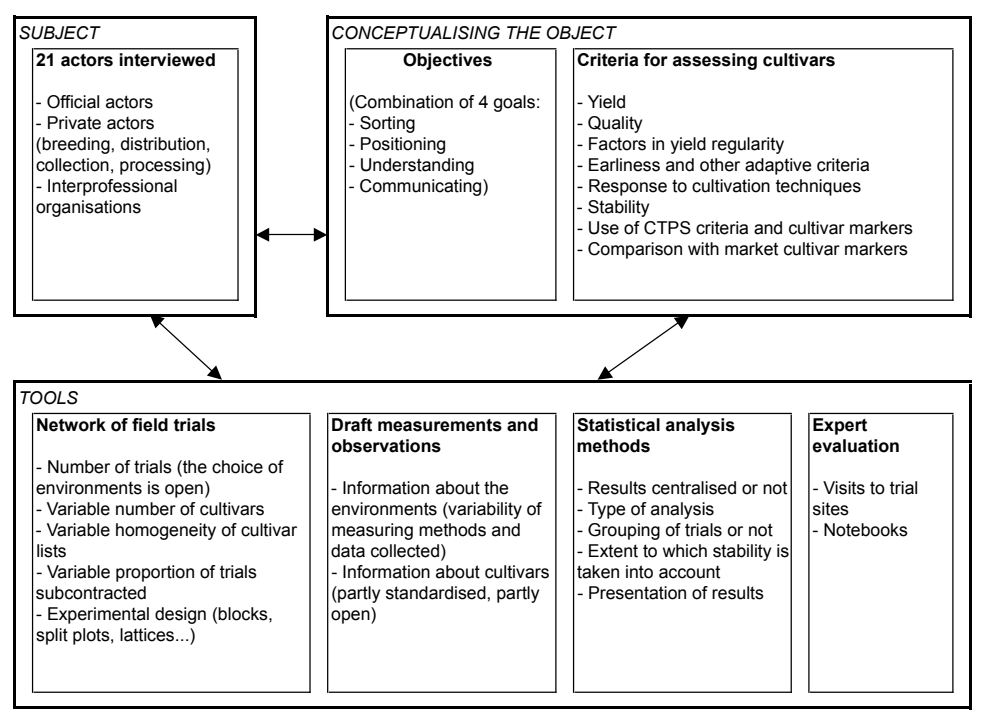

Figure 1: The characteristics selected to define objects and tools for actions in the activity of evaluating cultivars.

The choice of criteria is based on identifying the broad characteristics of the activity of evaluation, i.e. the organising principles of the activity, over and above the diversity observed (see 4.1.). Initially, we retained what was said during the interviews (see Appendix 2 for an example). Next the replies were sorted into three groups, which varied depending on the relevant criteria. Each group of replies was based on the differences that were a priori regarded as meaningful, and taking account of the diversity of the replies obtained. They may, for example, reflect the importance given to a particular criterion or the degree of increasing complexity in the operation which enables the actor to define a 
criterion (see Appendix 2). On the basis of those tables, we then used automatic classification methods to structure the diversity (software: SAS ${ }^{\circledR}$-SAS, 1999-2000-, «cluster» procedure). Firstly, that of ways of appreciating the object of the evaluation activity by using the goals set out by the actors and the criteria for assessing cultivars. Next, that of tools and ways of using them. Nonetheless, depending on the tools, a greater or smaller degree of diversity may be observed in the data. In fact the greatest diversity occurs in the network of cultivar field trials so this is what we attempted to structure by applying an automatic classification method, as we did in structuring the diversity of ways of appreciating the object of the activity. We then returned to the data from the interviews to establish the connection made by the actors between those categories which present the diversity of conceptualisations of the object of the evaluation on the one hand and those which present the diversity of network configurations set up by the actors on the other. It was the findings from this comparison that ultimately enabled us to describe the diversity of the evaluation actions.

\section{4.- Results of the analysis of evaluation actions for soft wheat cultivars}

\section{1.-Towards the crystallisation of a model for the activity of evaluation}

Traditionally, the concept of evaluation presumes the existence of choices and criteria for making them. In fact, traditional decision-making theories (for a bibliographical review, see Tsoukias, 2006) examine the range of criteria available (min-max, Savage, etc.) to define an algorithm of choice. Yet, as we pointed out in the Introduction, the actors are more interested in how data is collected and analysed than in procedures for choosing a cultivar that meets their objectives. We therefore focused our analysis on the former in order to bring out invariants for the activity of evaluation, based on our investigation of actions, which we will use to devise specifications. We also used the work of historians to understand how the activity of cultivar evaluation evolved historically.

\subsection{1.- A historically constituted «cultivar» object: the notion of cultivar stability}

The notion of a cultivar as it is understood today comes from the specific cultivar innovation system established following the second world war (Bonneuil, et al., 2006). In their historical study of the seed sector and plant cultivars, Bonneuil, et al. (ibid.) trace how, after the war, the concept of a cultivar came to be associated with that of a "pure variety", as opposed to a "population variety". The idea gained ground, both in research and among breeders, that a cultivar should be stable, distinct and homogeneous (three criteria that are also given in the official evaluation requested by the CTPS). Bonneuil, et al. (ibid.) report the case put by a researcher to explain why this definition of a cultivar found favour: "The advantage of a stable cultivar is that in theory it is possible to determine once and for all how it will react to the environment and cultivation techniques, and therefore to obtain the maximum yield" (Jonard, 1961, in Bonneuil, et al., 2006). The concept of a pure, stable cultivar was therefore seen as a way of controlling the interactions between the cultivar and its environment. The idea still occurs in the methods used by the various actors involved in evaluation, who are looking first and foremost for a stable cultivar in a range of environments. This is clear from the way they handle the results of field trials: they compare the average performance of a given cultivar, either to that of cultivars in other trials or to that of a cultivar marker. Nonetheless it is worth pointing out that the notion of stability may be applied to different spatio-temporal scales (local or national, annual or multi-annual) and to criteria that may vary (yield, protein content, performance in flour blends). Thus the notion of stability as conveyed by the CTPS standard is reinterpreted in various ways by the actors. 


\subsection{2.- Four tools at the core of the activity: historically established but unspecified}

Our data show that the collection and analysis of data are based first and foremost on the use of four tools: the network of cultivar field trials, the agreed methods for measuring and observing cultivars within the network, statistical analysis methods, and visits to the trial sites. Considering those tools by taking an interest only in the strictly cognitive dimension of data management, as too often happens in decision-oriented approaches to evaluation, amounts to denying the material aspect of the task of evaluation and the management of time and space needed in the case of cultivar evaluation. In order to evaluate cultivars, it is necessary to design and set up trials, to choose tools to observe certain characteristics of interest so that cultivars may be compared, to take account of the adaptive faculties of living things generally and, in order to do that, to ask questions about the variability of the relevant soil and climate conditions to be taken into account to allow for this effect, to reflect on the quality of the data collected and on how trials should be compared, etc.

It emerged from our interviews that for all the actors, the network of cultivar field trials is a key tool in the activity of evaluation. On the one hand it is an essential source of information about cultivar performance which must then be turned into data that can be processed; on the other it plays a central role among all the tools because it partly determines the methods used for measuring and observing cultivars and governs the choice of statistical analysis methods (for example, only a network in which all the trials are done with all the cultivars enables the most simple statistical methods, such as balanced analysis of variance, to be used.)

It is nonetheless important to underscore an interesting characteristic shared by the four tools we have just mentioned: their low level of predetermination which, it seems to us, is liable to make it easier to construct an instrument from them. A tool such as the field trials network, for instance, leaves wide open the question of how a trial or all the trials should be organised (number of cultivars grown, number of trials in the network, types of environment and the diversity explored, sharing of cultivars in the trials). Similarly, talking about agreed methods for measuring and observing cultivars leaves open both the type of observation that takes place and and the way data is collected. Finally, saying that statistical analysis methods are used to study the data arising from the network also leaves a wide choice as to the type of method. This is illustrated in Figure 1, which shows the structure of each tool and the choices that it offers. We also wish to emphasise that the tools are the result of both the historical development of the activity of trials, which made it possible to carried out a structured analysis of the adaptive performance of living organisms in various environments, and of the introduction of the cultivar innovation system established after the second world war (Bonneuil, et al., 2006). Against this background, certain norms arose concerning the tools and the way they were used. For instance, all the actors interviewed put forward the same norms regarding setting up a trial to restrict the effects of soil heterogeneity (trials in randomised blocks), the notion of "cultivar markers" to provide a point of comparison with the cultivars whose performance is under scrutiny, the use of a method for reporting the extent to which a cultivar was affected by disease, and the use of statistical techniques regarding the comparison of averages to estimate the relative interest of a cultivar. However, the existence of these norms does not negate the possibility of enormous variability in the way the tools are actually implemented, as we shall see in paragraph 4.2. So the main tools used in the activity are open to instrumentalisation and instrumentation procedures by the actors, but also form the basis of historically established norms on how to evaluate cultivars.

\subsection{3.- An activity subject to regulations and constraints regarding time and organisation}

Data from the networks used for evaluation are sometimes collected directly during visits to the trial sites, but are most often supplied at the end of the season by experimenters to whom the task is subcontracted. Some data may require laboratory work (especially for technological tests to produce data on bread-making criteria), but here too the work is often subcontracted. This means that the actual evaluation can only really begin once the production results have been obtained (yield, in metric tons of grain/hectare, plus data about milling performance which often arrive much later), although 
discussions between evaluators and experimenters throughout the growing cycle will already have given the former a glimpse of what to expect. The evaluators then have a great deal of information to process in a short space of time, especially in the case of wheat growing in France, where the cycle lasts from October to July. The evaluation must be completed before the new season starts, which means during August and September, although some investigations can be taken further during the winter to confirm the trends identified. Practically speaking, the actors told us that they sometimes had only two days to summarise their findings after receiving the trial results before a new round of trials began. These time constraints were amply commented on by all the people interviewed.

The interviews showed that the way the work of data collection is shared out and the time frame of the wheat growing cycle have an impact on the evaluators' ability to gather all the data they feel are necessary to make an evaluation. The activity of evaluation requires them to negotiate and coordinate their work with that of other actors, of whom there are even more when the networks involved are large (e.g. on a national scale). A system for measurement and observation must also be negotiated, as well as the exchange and loan of equipment for setting up the trials. All information has a financial cost, as does the accuracy of the measuring: the cost of setting up trials, the cost of acquiring additional information, costs that arise because some data cannot be used due to the heterogeneity of the environment, etc.

These constraints (time management, sharing of work between partners, cost of collecting and analysing data on cultivar performance) influence the way the actors use, and fashion as instruments, the tools of the field trials network, data collection and processing methods. In particular, they influence the specific content given to those tools; in other words, they structure the way in which the actors make the tool a resource for their evaluation action. To work around the constraints, the actors have come up with a few «rules»: visits to the trial sites alleviate partnership problems, while developing standardised methods and requesting intermediate summaries for the trials help to reduce the time constraints and facilitate relations between the partners.

\subsection{4.- Initial specifications for the tool}

Figure 2 gives an overview of the activity of evaluation, particularly the object, tools, rules and constraints that we have identified.

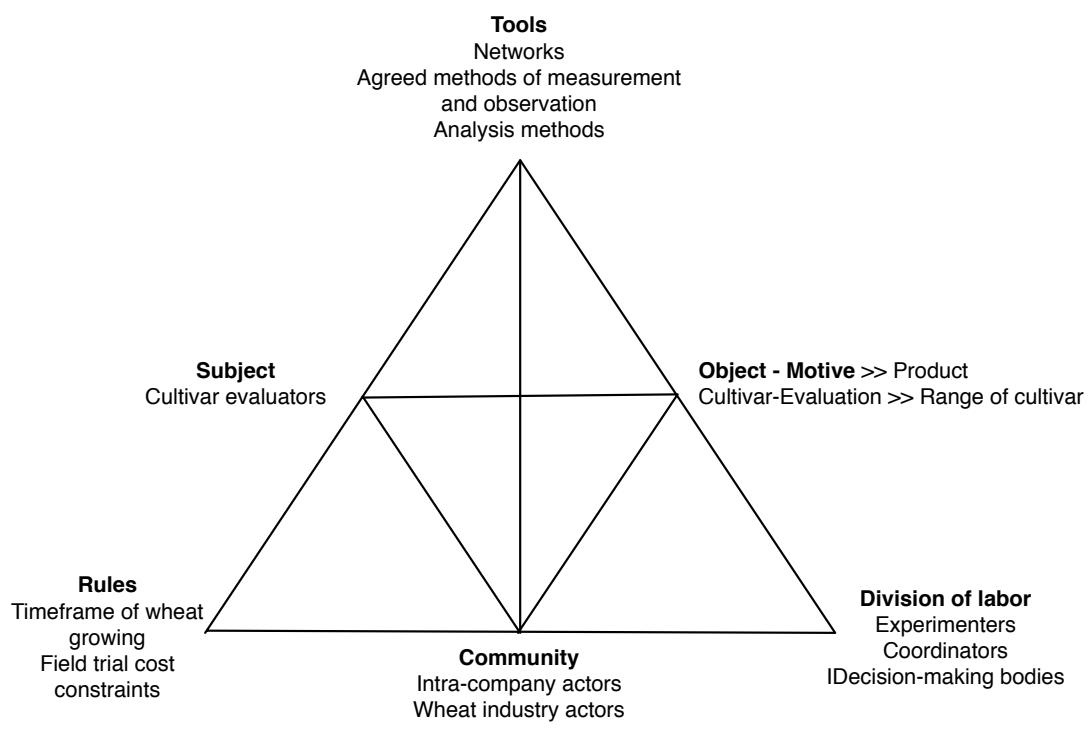

Figure 2: The activity system for cultivar evaluation.

Some specifications have been built up on the basis of this model. The tool to be designed must enable the actors to assess the stability of a cultivar's performance on the basis of the criteria and the time and space constraints they have selected. Moreover, it must allow for the coexistence of various 
tools and the way in which the cultivar field trials network tends to organise them. Similarly, the constraints of network management and division of labour between actors mean that we are seeking first and foremost a tool which puts the data available to the best possible use to expand the actors' knowledge about the cultivars, excluding solutions which would merely increase the quantity of data (by adding either more trials or more observations), unless those additions seem to be a conclusive way of improving the analysis. Such solutions should take account of the need to keep down the cost of trials and the time taken to obtain information. Finally, given the time constraints related to the cycle of wheat cultivation, the solutions put forward to make the best use of the available data must be quick to implement. Automation of analysis procedures is therefore desirable.

\section{2.-Towards the flexibility of the tool to be designed}

Taking account of all the foregoing, the activity of evaluation implies the ability to make decisions about cultivars on the basis of data which are often incomplete and not very accurate. Knowing how to extract relevant information from the data collected and what criteria should be used to assess the cultivars are therefore key skills for an evaluator. The criteria will not necessarily be the same for different actors because they may have their own specific objectives. As Leont'ev (1977) points out, while the notion of "motive" is inherent to that of activity, the notion of "objective" is inherent to that of action. For example, breeders evaluate cultivars to decide whether to submit a new one for registration ${ }^{1}$, developers will attempt to identify the market share that a cultivar going through the registration process may achieve, technical advisers will be trying to define situations in which the cultivar can reach its full potential, and so on. This is why we must draw a distinction between the physical aspect of the cultivar (a plant with identifiable physiological and genetic characteristics) and its conceptual dimension - which brings us back to the objectives of evaluation and the related criteria that make it possible to describe the cultivar according to those objectives. There is potential diversity in the conceptual dimension of the cultivar as an object, which we can understand due to the diversity of objectives and criteria used for evaluation. Diversity, as mentioned earlier, may also be seen in the way the actors turn the tools into instruments. These two factors - diversity of objects (in their conceptual dimension) and diversity of instruments - allow us to structure the diversity of evaluation actions so that we can formulate specifications for the tool to be designed. Figure 1 shows the indicators on which we focused in order to understand the diversity of the actions.

\subsection{1.- Diversity of conceptualisations of the cultivar object}

In order to describe the diversity of conceptualisations of the cultivar object developed by the actors, we analysed the objectives the actors set themselves and the resulting cultivar assessment criteria.

Table 2 shows that what constitutes an objective for a particular actor is a combination of four goals that he/she quotes as making up the task of evaluation: (1) sorting cultivars; (2) positioning them either geographically or compared to the market; (3) studying them; (4) devising a system for communication and visits. The table also shows that some criteria were emphasised more than others to achieve certain goals.

The first goal (sorting cultivars) is more a matter of eliminating cultivars than of classifying them. According to the actors, the criteria related to this goal may vary depending on whether they are trying to: (a) eliminate cultivars which did not perform well enough compared to cultivar markers²;

1. Drawing up a registration application is expensive and the registration itself has to be paid for. Above all, the registration «tests» are based on the idea that the new cultivar must show some progress compared to those already on the market. This progress is assessed using various criteria: yield is a major one, balanced by factors such as quality for breadmaking and resistance to disease and lodging.

2. The notion of cultivar marker is very important in the activity of evaluation. In all field trials, cultivars whose performance is well known, and/or which already have substantial market share, are also grown. Those cultivars are used as a basis for comparison with the new cultivars coming onto the market, in the hope that the latter will offer improved performance. 
(b) eliminate those that were ruled out by other factors, particularly because they were unsuitable for specific environments. "Sorting" means selecting cultivars that are liable to win market share as part of a range of cultivars, or choosing a cultivar according to its ability to stand in for an existing cultivar in a market niche.

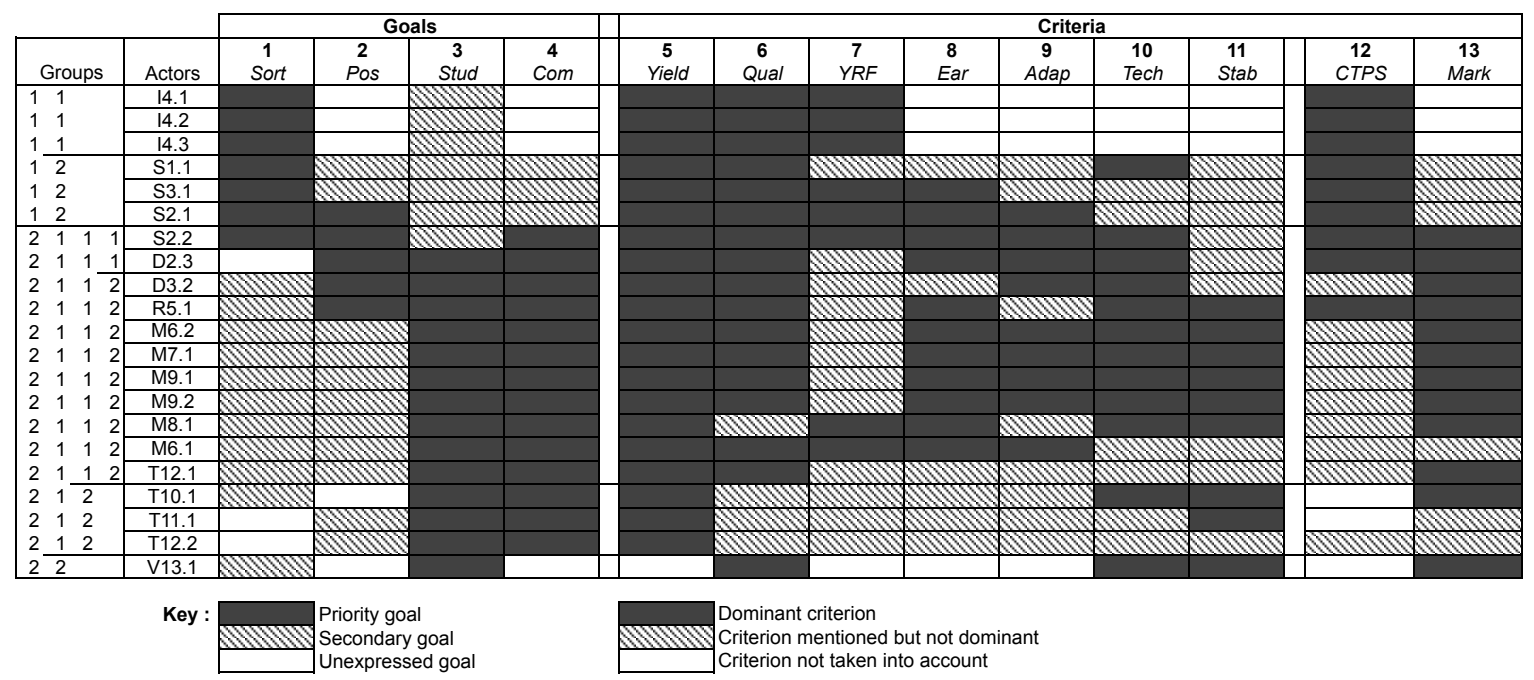

Table 2: Actors' goals and the genotype assessment criteria given by them, sorted automatically.

Goals: Sort; Pos. = position; Stud = study; Comm. = communicate.

Criteria: Yield; $Q u a l=$ quality; $Y R F=$ yield regularity factors; $E a r=$ earliness; Adap $=$ other adaptive criteria; Tech $=$ response to cultivation techniques; Stab = performance stability; CTPS = use of CTPS markers and criteria; Mark = comparison markers chosen by the company.

Groups: result of automatic classification using the SAS ${ }^{\circledR}$ «cluster» procedure.

The second goal (positioning cultivars) covers two meanings: (a) positioning geographically; in other words, deciding exactly where a cultivar should be grown; (b) positioning with a view to marketing; in other words, assessing the market potential of a new cultivar. The cultivars are compared to cultivar markers chosen by the company according to either the market or the geographical area it covers. The most closely monitored performance criteria, apart from yield and milling quality, are earliness, response to cultivation techniques and ability to make up lost ground during a cycle (tillering capacity, weight of seeds).

The third goal (studying the cultivars) obviously involves studying their performance in terms of yield and quality, but it also means assessing their stability and degree of adaptability to variations in cultivation techniques (dates, sowing density, nitrogen fertilisers, ...). To assess stability, criteria regarding resistance to cold, disease and lodging are taken into account, along with the characteristics of the evaluation environment (e.g. resistance to cold in north-eastern France). The cultivars are mainly compared to "market" cultivar markers selected by each company, and are also classified according to earliness and quality.

The fourth goal (communicating information about the cultivars) is more closely connected with the job of conducting field trials and the resulting opportunities to observe the cultivars in their natural situation. The trials are the subject of organised visits, which is why the evaluators also give weight to the visual appearance of the cultivars. Visual comparisons may concern the extent of lodging or disease at a trial site, as well as cultivars' response to cultivation techniques such as fungicidal treatments and the date and density of sowing. These criteria may then acquire importance in the work of evaluation.

Carrying out an automatic classification based on a combination of goals and criteria chosen by the actors enables us to distinguish six different ways of conceptualising the object of the activity of 
evaluation (see Table 3), which we have called "Registering", "Breeding", "Developing", "Range designing", "Indexing" and "Scoring technological suitability".

\begin{tabular}{|c|c|c|c|c|c|c|}
\hline & $\begin{array}{c}\text { Conceptualisation of the } \\
\text { cultivar object }\end{array}$ & Priority goals & $\begin{array}{c}\text { Secondary } \\
\text { goals }\end{array}$ & Dominant criteria & Secondary criteria & Markers \\
\hline 1 & $\begin{array}{l}\text { Registering } \\
\text { New cultivar }\end{array}$ & Sort & Study & $\begin{array}{l}\text { Yield, Quality, } \\
\text { Yield regularity } \\
\text { factors }\end{array}$ & & CTPS \\
\hline 2 & $\begin{array}{c}\text { Breeding } \\
\text { New cultivar }\end{array}$ & Sort & $\begin{array}{c}\text { Position } \\
\text { Study } \\
\text { Communicate }\end{array}$ & $\begin{array}{l}\text { Yield, Quality, } \\
\text { Yield regularity } \\
\text { factors }\end{array}$ & $\begin{array}{l}\text { Earliness, Other } \\
\text { adaptive criteria, } \\
\text { Sensitivity to } \\
\text { techniques, Stability }\end{array}$ & $\begin{array}{c}\text { CTPS } \\
\text { (Market) }\end{array}$ \\
\hline 3 & $\begin{array}{c}\text { Developing } \\
\text { New cultivar selected by } \\
\text { the company }\end{array}$ & $\begin{array}{c}\text { Position } \\
\text { Study } \\
\text { Communicate }\end{array}$ & Sort & $\begin{array}{l}\text { Yield, Quality, } \\
\text { Other adaptive } \\
\text { criteria, Sensitivity } \\
\text { to techniques }\end{array}$ & $\begin{array}{l}\text { Stability, Yield } \\
\text { regularity factors }\end{array}$ & $\begin{array}{l}\text { CTPS \& } \\
\text { Market }\end{array}$ \\
\hline 5 & $\begin{array}{c}\text { Indexing } \\
\text { Registered cultivars }\end{array}$ & $\begin{array}{c}\text { Study } \\
\text { Communicate }\end{array}$ & Position & Yield, Stability & $\begin{array}{l}\text { Quality, Other } \\
\text { adaptive criteria, } \\
\text { Sensitivity to } \\
\text { techniques, Yield } \\
\text { regularity factors, } \\
\text { Earliness } \\
\end{array}$ & Market \\
\hline 6 & $\begin{array}{l}\text { Scoring technological } \\
\text { suitability } \\
\text { Registered cultivars and } \\
\text { cultivar combinations }\end{array}$ & Study & Sort & $\begin{array}{l}\text { Quality, Sensitivity } \\
\text { to techniques, } \\
\text { Stability }\end{array}$ & & Market \\
\hline
\end{tabular}

Table 3: Conceptualisations of the cultivar object identified and their characteristics, classified automatically on the basis of goals and criteria given by actors (for the criteria, see the key to Table 2).

This classification shows us that some of the diversity is related to the stages that make up the life cycle of the cultivar, from creation to utilisation. However, it also highlights the fact that the way an object is conceptualised does not always correspond to an occupation. Thus, while some breeders have conceptualisations that are close to those of the people in charge of registration, the ideas of others are close to those of the developers. This confirms the need to look beyond the labels that actors may have in order to gain a better understanding of their involvement in the work of evaluation.

\subsection{2.- Diversity of the instruments}

\section{Diversity in the ways cultivar field trials are set up}

Analysing the interviews brings out, first and foremost, the fact that the same actor may choose to set up several different networks, defining specific values for the various elements that make up those networks. We identified a total of 39 different networks for the people we surveyed. The network characteristics appear to be linked to the relevant stage in the life cycle of the cultivar and to the geographical scale on which the evaluation is carried out.

Overall, during the life cycle of a cultivar, a regular reduction in the number of cultivars tested in the course of the same trial, with a correlated increase in the number of environments, may be observed. The scale of the evaluator's action (local, regional or national) also influences the number of trials and the homogeneity of cultivar lists ${ }^{3}$. We also noted that most of the actors working on a national

3 Homogeneity means here that the same set of cultivars was used in all the trials. For example, in the registration trials, the lists are different between northern and southern areas. Delegating trials to cooperatives may lead, therefore, to greater heterogeneity because each cooperative wants to test the cultivars it expects to be able to market subsequently. 
level subcontracted their trials more often, which tends to increase the heterogeneity of the cultivar lists.

Along the cultivars life, the trial methods used (how repetitions within a trial are organised) are simplified. In other words, the methods may be complex when breeders are trying to restrict the scale of the trials while maintaining control of the heterogeneity of the environment with a large number of cultivars to be tested, and simpler in later trials. The role of experimental show platform which is allotted to the trials - particularly for multiplier-distributors - results in a greater number of repetitions, with one plot systematically treated with fungicides and another nearby left untreated to see how sensitive the cultivars are to disease. The importance given to the performance of batches not treated with fungicides tends to fall over the cultivars' life cycle. Conversely, the cultivars' responses to varying doses of nitrogen and to sowing density are only studied after the registration phase because this makes it easier to evaluate their performance in response to various cultivation techniques.

The automatic classification of the 39 networks, carried out on the basis of these criteria, enabled us to distinguish nine types of network (see Table 4), which we called the: "Registration", "Start of breeding process", "End of breeding process", "Indexing of company's new breeds", "Commercial development", "Seed producers", "Technical-commercial indexing", "Technical indexing" and "Milling" networks. Here again, these titles do not fully correspond to the occupations usually identified in the industry.

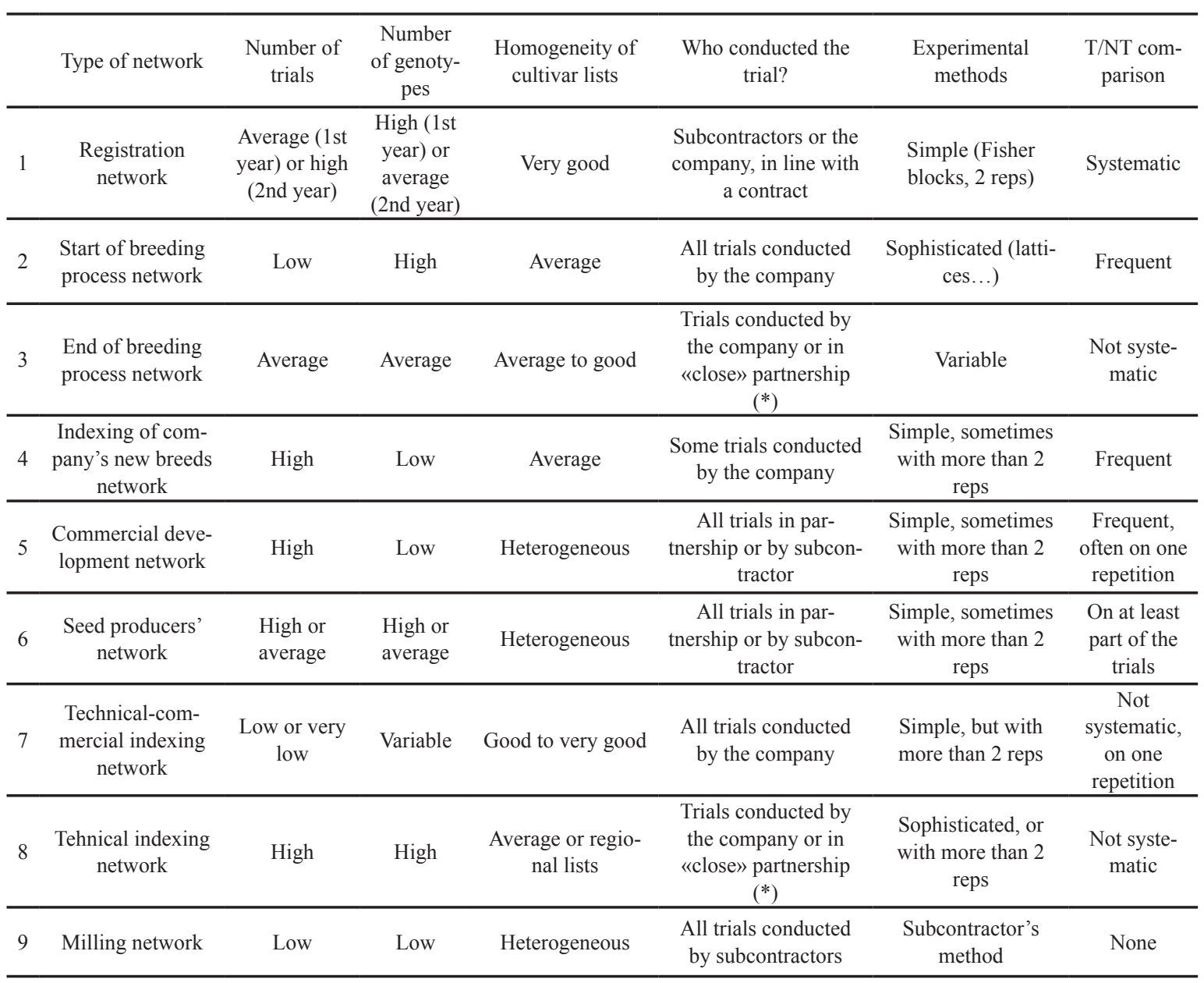

Table 4: The nine types of network and their characteristics.

(*) A «close» partnership is one between companies involved in the same business (e.g. breeding) and which usually cooperate by carrying out some of their trials jointly.

\section{Diversity of methods and of trial data collected}


The interviews brought out a great diversity in the data collected. Nonetheless, the following were systematically measured in the cultivars: (a) synthetic variables (yield, breadmaking quality), and (b) easy-to-collect data giving information about criteria that are generally agreed to be a source of variation: earliness (measured by earing date), resistance to disease and lodging (assessed by recording symptoms). Regarding data about environments, the type of soil and previous crop are always known, but data on climate are not very often recorded, even simple statistics such as rainfall and temperature. The actors collect information about the environments in order to assess how representative the trials are compared to other potential growing areas for a cultivar, or to identify trials taking place on heterogeneous soil, which often prove less reliable.

It should also be emphasised that few tools are used in data collection, even though such tools exist and could provide precise information (e.g. tensiometers and a means of calculating water balance which are tools to assess the degree of water stress). So environmental factors that might cause yield variations are almost always assessed intuitively. Data on factors that might affect yield are often recorded during visits to trial sites and therefore depend on the expertise of the people making the visit. The data, recorded in a notebook which the expert keeps with him or her at all times, aim to provide a general key to understanding why a trial or a cultivar fails. The trial visit, which complements the other observation methods, is both a source and a product of the expertise of various actors. The notebook is often used by the evaluator when processing the data provided by experimenters.

\section{Diversity of tools for processing data and analysing results}

The data produced by the trials are usually processed in two stages: (1) the results of each trial are analysed by the experimenter; (2) data covering all the trials in the network are brought together and summarised by the same person. Usually the analysis of each trial takes the form of a simple analysis of variance, with an overall mean for the trial, a coefficient of variation and/or residual standard deviation, and a Newman-Keuls test, which enables the cultivars to be classified into statistical groups and the «quality» of the trial to be assessed (low coefficient of residual variation). When the network comprises only a few trials, the summary may consist of merely placing the results of the various tests side by side (certain breeders do this, for example). More often than not, the summary involves taking the mean of the yield results for each cultivar in the network, either as a percentage of the cultivar markers or of the overall mean. Some actors display the variability of results, usually in graph form. In some rare cases, an overall analysis of variance for the network is carried out, requiring sophisticated statistical tools (for the analysis of unbalanced data). As mentioned above (§ 4.1.1.), the chief aim of such analysis is to assess the stability of a cultivar.

Our interviews highlighted little diversity in the methods used to analyse and coordinate data, despite high variability in networks and in the data collected from networks described in the previous two paragraphs. The analysis is usually based on simple statistical tools and calls on the - usually informal - expertise of the evaluators along with the observations made during visits to trial sites. This means comparing the results of tests with very general environmental characteristics, such as soil type, rainfall or the soil's ability to encourage plant growth at the end of winter. The evaluators' knowledge is used to gain a better understanding of the instability of a criterion for a particular cultivar, or to assess the relevance of retaining the results of a particular trial in the overall analysis.

Analysing diversity also enables us to ask questions about how the various tools may or may not be interconnected and how they constitute a system. On the contrario, our data show, for instance, that it is harder to obtain detailed information about environments in networks where many trials are taking place, especially when the trials are conducted mainly by partners or subcontractors. It is also in this type of network that the organisation of the trials is simplest, and that there is the least variation in cultivation techniques. The data collected about cultivars are only very loosely connected with how the networks are organised. For example, when the networks are managed to a large extent in partnership or by subcontractors, the shortage of information that may result is compensated for by visits to the trial sites. The evaluators' expertise makes up for the limited and uniform nature of the data measured by experimenters in the network as a whole. Finally, the relative homogeneity of data 
processing (calculating means for each cultivar in the network, calculating variations between cultivars for a single trial) may seem surprising in view of the diversity of network configurations. In fact there are statistical tools that might be more useful in finding appropriate kinds of processing for the different configurations so as to produce lists of criteria that the actors would find relevant in assessing cultivars. The actors say that they do not know enough about statistical analysis methods.

\subsection{3.- Diversity of actions: new specifications}

We suggest considering that it is a combination of the various conceptualisations of the cultivar object and the various network configurations that gives the clearest picture of diversity on the level of actions. In fact, our research on the invariants of the activity showed that the field trials network is the key tool in the activity. The 11 actions that we distinguished ties in with the link the actors made between how the cultivar object are conceptualised and how the network are configured (Table 5).

\begin{tabular}{|c|c|c|c|}
\hline & Actions & $\begin{array}{c}\text { Conceptualisation of the } \\
\text { object }\end{array}$ & Configuration of the network \\
\hline 1 & Registration & Registering & Registration network \\
\hline 2 & Start of breeding & Breeding & Start of breeding process network \\
\hline 3 & End of breeding & Breeding & End of breeding process network \\
\hline 4 & Development-Indexing new breeds & Developing & Indexing of company's new breeds network \\
\hline 5 & Commercial development & Developing & Commercial development network \\
\hline 6 & Developing a range of seeds & Range designing & Seed producers' network \\
\hline 7 & Technical-commercial indexing & Range designing & Technical-commercial indexing network \\
\hline 8 & National technical indexing & Range designing & Technical indexing network \\
\hline 9 & Regional technical coordination & Indexing & Technical indexing network \\
\hline 10 & Local technical-commercial indexing & Indexing & Technical-commercial indexing network \\
\hline 11 & Milling & Scoring technological & Milling network \\
\hline
\end{tabular}

Table 5: Diversity of actions in cultivar evaluation

Some objects, such as "Registering" and "Scoring technological suitability", correspond to highly specific network configurations, but usually matters are more complex. Different configurations may correspond to the same conceptualisation of an object: for the «Breeding» object, we identified two actions, "Start of breeding" and "End of breeding", because the trial networks differ on practically all the descriptive criteria we selected (see Table 4). This is also the case with the "Developing" object, for which we identified the actions of "Indexing of company's new breeds" and "Commercial development" because the trials networks differ on two criteria in particular: homogeneity of the cultivar lists and the proportion of trials subcontracted. We linked three actions with the "Range designing" object: "Developing a range of seeds", "Technical-commercial indexing" and "National technical indexing". This is because the related network configurations differ according to several characteristics: number of trials, homogeneity of cultivar lists, proportion of trials carried out by the company or by a subcontractor, and trial organisation. Finally, two actions, "Regional technical coordination" and "Local technical-commercial indexing" were related to the same object (Indexing), and each had a network configuration close to the two previous actions (respectively, the Technical indexing network, shared by "National technical indexing", and the Technical-commercial indexing network, shared by the action of "Technical-commercial indexing". So it can also be seen that the same type of network may be used in conjunction with various conceptualisations of the cultivar object.

We can draw two new lessons from these observations that will be useful in designing the tool. The diversity of actions is a reason for leaving multiple choices to the actors during their data processing operations. Even so, our findings show that there is not always a one-to-one relationship between how a cultivar object is conceptualised and a given network configuration. Therefore finding an appropriate tool for the diversity of actions is perhaps less relevant than finding an appropriate tool for the diversity of conceptualisations on the one hand and of configurations on the other. We suggest, therefore, that the tool's outputs should be adjusted to suit the objectives and evaluation criteria of 
each actor. For example, some will want an output from which it will be possible to exclude cultivars according to certain criteria, while others will want to see how a new cultivar is placed in a range designed to meet the actor's specific criteria. So what matters here is to plan various ways of presenting the analysis output or to give actors access to raw output data, leaving them free to decide on the presentation. The tool should also allow them to work on different network configurations, with heterogeneous cultivar lists and missing data where appropriate. As we have pointed out, individual expertise often enables actors to make up for these "information gaps". Such actors will want to include their own expertise, for example by adding observations made during visits to trial sites which they believe may account for differences between environments, or even differences in cultivar performance. A procedure should therefore make it possible to highlight this kind of information while also taking account of how precise it is. Expertise also matters when the analysis is being carried out: an actor may want to alter the way the trials are grouped according to their ability to distinguish the main types of agronomic constraint. This procedure should enable the actors to use their expertise in the output produced by the tool.

\section{3.-Towards the tool as a mediator for development}

We have suggested that if the tool is to become a source of development for the activity, it should highlight both the contradictions that arise within the activity of evaluation and ways of overcoming them. The main contradiction seems to us to be situated somewhere between the necessity acknowledged by all the actors to move the activity of evaluation forward to deal with the challenges of greater diversification in expected performance and technical procedures on the one hand, and focus on performance stability analysis in cultivar evaluation actions on the other. If stability and analysing performance diversity are the two faces of the Janus of evaluation, the relative weight given to one or the other changes the way in which the evaluation tools will be used, and may result in differing data needs.

\subsection{1.- Contradiction between the quest for stable performance and the need to take account of varying cultivar performance in a range of environments}

Our analysis of the data processing carried out by the actors shows that they are attempting to characterise the stability of a cultivar's performance, whether that stability is evaluated in absolute terms (mean and standard variation), in relation to cultivar markers or in relation to the overall mean in the network. This type of processing does not require precise knowledge of the prevailing agronomic conditions. At best, evaluation of performance stability is based on the expertise built up by the actors, drawing mainly on comments on observations made in the field which seek to explain the varying performance of such and such a cultivar in a given trial.

This type of analysis cannot explain whether an environmental factor is the main reason for the difference in performance or how a combination of factors may operate, yet nowadays evaluators are expected to know how cultivars perform in a very wide range of growing conditions. The actors are aware of this discrepancy and say that they are not equipped to produce the information. The problem highlights the fact that it is impossible, using statistical tools and the expertise available, to conduct an overall analysis of the variations observed in the network as a whole. Finally, a network is more often regarded as a collection of independent trials rather than a complex structure in which the results have an overall consistency which can be updated. The tool must be able to help the actors to go beyond their current analysis, which is based on comparing pairs of trials, and to recognise that consistency. They must be given the means to conduct an analysis of the whole network, using to best advantage all the information available to them, whether this is the result of measured data or of their own expertise. Thus, to help actors to understand the difficulties they encounter in producing the information that is increasingly requested by their customers, we suggest (a) that the tool should enable analysis to take place on the scale of a network and (b) that it should show how the analysis clarifies the diversity of agronomic conditions in the trials. 


\subsection{2.- Contradictions between the data collected and limiting factors which the actors want to pinpoint}

Although most actors are aware that the explanation for differences in results lies in the characteristics of environments, they have little quantified information about those environments. They wonder, therefore, how to increase their knowledge of the environments in order to identify favourable situations or explain falling yields (the actions of registration and end of breeding), as well as to decide how best to adapt cultivars to environmental characteristics or to different cultivation techniques (the actions of commercial development, indexing of a company's new breeds, and national and local technical indexing). Our analysis also underlines the problem of collecting data about environments, taking account of how the trials are organised. This problem is more or less acute depending on the action: it is more acute in the case of registration, national technical indexing, commercial development and indexing of a company's new breeds. However, some actors believe it is possible to quantify the information by using easily accessible data on environments (e.g. by purchasing climate data from Météo-France, the French weather authority). But they still feel ill-equipped to make the best use of the data. We suggest that the tool should take advantage of the existence of more precise data for certain networks to demonstrate the possible value of collecting such data, or to demonstrate what is being lost by not including them.

Be that as it may, agronomists are facing the need to describe the limiting factors that explain differences in cultivar performance from one environment to another. Which should be used first if it is impossible to measure them all? How can the quantity of information to be measured be kept to a minimum? Agronomists have envisaged using cultivars whose yield formation ${ }^{4}$ is well known (they call these probe genotypes) to highlight the limiting factors that arise in a given environment. It is then possible to see how such factors affect new cultivars. Is this proposal, which would change the ways information is collected, be acceptable to the actors? Here too, the tool must be able to demonstrate the advantage of the procedure, which will have an impact on data collection methods and on the list of cultivars at a site.

\section{5.- Conclusion}

Our analysis of the activity of evaluating soft wheat cultivars is contingent on our objective: to design a tool to help with the analysis of data on cultivar performance when facing a range of agronomic constraints. We conducted it with a view to linking three aspects in the design process: crystallisation, flexibility and development. The activity-based approach, which we chose to identify the user model and the activity to be crystallised in the tool, involves looking for characteristics that are inherent to the activity as they were built up historically.

This analysis leads us to underline the importance of the notion of stability in defining the cultivar object as it was established after the second world war, a notion that turns out to be understood differently depending on the evaluation actions carried out today, and which may act as a brake on responding to the new demands of evaluation. It also highlights the tools used in the activity of evaluation, any interdependency between them which should be taken into account and their historical construction, as well as how much room for manoeuvre is left open to the actors. It points out the time constraints that must be respected in analysing data and evaluating cultivar performance, in addition to the need to reduce the costs involved in collecting the data used in the evaluation process.

Our focus on the diversity of the actions that make up the activity of evaluation nowadays is based on identifying the diversity of conceptualisations that the actors have of the cultivar object and the

4. The notion of yield formation makes it possible to understand how a final aspect of performance (yield, for instance) is the result of a process involving growth, development and the provision of nutrients within a plant community. Yield is formed through various components, between which compensatory phenomena may exist. For more details, see Sebillotte (1980). 
diversity of ways to transform tools into instruments. This led us to identify 11 different evaluation actions, which represent ways of envisaging the collection and processing of data needed for evaluation. From this, we deduced the need to ensure flexibility in using the analyses produced by the tool. In particular, it is necessary to propose outputs suited to the range of conceptualisations. Similarly, we deduced the need for flexibility in the input data to take account both of the diversity of configurations in cultivar field trials, a key tool in evaluation, and of the role of expertise in collecting and processing data from the networks.

Finally, we looked at this analysis of the activity and the diversity of actions in the light of the new demands facing the activity of cultivar evaluation to pinpoint how to represent in the tool any contradictions in the activity system, because these contradictions could become driving forces for future development of the activity and for using the tool thus designed. We pinpointed two major contradictions. The first is the contradiction between the quest, shared by all the actors, for performance stability and the increasing emphasis on the need to evaluate how cultivars are suited to different environments or specific growing conditions. The second is the contradiction between the information collected and the desire to pinpoint certain limiting factors in the networks. We suggest that the tool should help to resolve these contradictions by showing what an overall analysis of the network can contribute compared to current analyses, while at the same time taking account of the changes in data collection methods that would be required. It is a question of allowing the actors to decide what they stand to win or lose by taking this path.

Nonetheless, we must point out that the specifications we have reached may be subject to some tension. Although the model of activity we have selected leads to a recommendation not to increase the amount of information to be produced, it is necessary to envisage collecting more information about environmental factors that limit cultivar performance in the network in order to overcome the contradictions identified in the activity. The solution put forward (focusing on what agronomists call probe genotypes) may eliminate the tension, as long as it is possible to make the necessary changes to data collection methods and their implementation. Another source of tension may arise between the specification of a tool suited to the actors' expertise and the recommendation to analyse data at network level. The actors' expertise, which some of them have built up around the notion of stability, is bound to be out of kilter, to a certain extent, with analysing how cultivars are suited to specific environmental conditions, which is made possible by analysis at network level.

In both instances, we think that only having the actors test a prototype will make it possible to discuss possible sources of tension with them, either to call the design choices into question or to make changes in their evaluation actions, over and above the activity as a whole. This is the task that we have undertaken subsequently. A form of analysis based on agronomic diagnosis (Sebillotte, 1980; David, Jeuffroy, Henning, \& Meynard, 2005) and conducted using so-called probe genotypes and statistical analysis methods (multiple regression and factorial regression) was developed (Lecomte, 2005), then implemented as a prototype (DIAGVAR).

We are planning to set up the tool as a way of developing: (a) the activity of evaluation by moving the object, particularly by demonstrating how to use network data to go beyond the narrow evaluation of stability; (b) the actions of the various actors, particularly by setting up the conditions for creating instruments and reflecting on their actions (to do this, we suggest letting them use the prototype with their own past data which they have already analysed); (c) the activity of modelling, particularly by clarifying the difficulties encountered by the actors in implementing the model using sets of data which they have chosen to analyse. Introducing these interactions around the prototype is aimed at enabling the exchange of learning experiences between designers and users (Béguin, 2003), as well as encouraging actors to think about the issues and to undertake a cycle of expanding the activity on a slightly different basis from that of Change Laboratory, as recommended by Engeström, Virkkunen, Helle, Pihlaja and Poikela (1996). In fact, while taking up the idea of supporting development by pointing out what actors see as contradictions in the activity system, we hope to show them to the actors through the use of the protype when, for these authors, contradictions are revealed by making 
available a representation of the activity system and a debate on the object of the activity. Whatever the truth of the matter, it is only after this work has been completed that we will truly be able to evaluate how we managed to incorporate a developmental aspect into the process of designing the tool, and possibly add to the typology of developmental interventions as suggested by Virkkunen (2006).

\section{REFERENCING}

Prost, L., Lecomte, Ch., Meynard, J.-M., \& Cerf, M. (2007). Designing a tool to analyse the performance of biological systems: The case of evaluating soft wheat cultivars. @ctivités, 4 (2), pp. 54-76, http://www. activites.org/v4n2/v4n2.pdf

\section{REFERENCES}

Béguin, P. (2003). Design as a mutual learning process between users and designers. Interacting with Computers, 15 (5), 709-730.

Béguin, P. (2005). La simulation entre experts : double jeu dans la zone proximale de développement et construction d'un monde commun. In P. Pastré (Ed.), Apprendre par la simulation, De l'analyse du travail aux apprentissages professionnels (pp. 55-77). Toulouse: Octarès Editons.

Béguin, P. (2007, à paraître). L'ergonomie en conception : cristallisation, plasticité et développement. In A. Hatchuel, \& B. Weill (Eds.), les nouveaux régimes de la Conception. Paris: Vuibert.

Blanchet, A., \& Gotman, A. (1992). L'enquête et ses méthodes : l'entretien. Paris: Nathan Université Sociologie. (Collection 128).

Bonneuil, C., Demeulenaere, E., Thomas, F., Joly, P.B., Allaire, G., \& Goldringer, I. (2006). Innover autrement? La recherche face à l'avènement d'un nouveau régime de production et de régulation des savoirs en génétique végétale.In P. Gasselin, \& O. Clément (Eds.), Quelles variétés et semences pour des agricultures paysannes durables? (pp. 29-51). Paris: Dossiers de l'environnement, vol 30.

Campariol, L. (1992). Blé tendre : Le turn-over variétal en chiffres. Semences et Progrès, 71, 8-14.

Cerf, M., \& Hochereau, F. (2004). Propositions de scénarios d'évolution des pratiques d'échange d'informations pour l'évaluation des variétés de blé tendre. Séminaire «Impact des innovations variétales » des 16 et 17 décembre 2004, Grignon: ATS de l'INRA.

David, C., Jeuffroy, M.H., Henning, J., \& Meynard, J.M. (2005). Yield variation of organic winter wheat: a diagnostic study in the Southeast of France. Agronomie, 25, 213-223.

Engeström, Y. (1987). Learning by expanding: An activity-theoretical approach to developmental research. Helsinki: Orienta-Konsultit.

Engeström, Y., Virkkunen, J., Helle, M., Pihlaja. J., \& Poikela, R. (1996). The Change Laboratory As A Tool For Transforming Work. Lifelong Learning in Europe, 1 (2), 10 -17.

Kuutti, K. (1995). Activity Theory as a potential framework for human computer interaction research. In B. Nardi (Ed.), Context and Consciousness: Activity Theory and Human Computer Interaction (pp. 17-44). Cambridge: MIT Press.

Lecomte C. (2005). L'évaluation expérimentale des innovations variétales. Proposition d'outils d'analyse de l'interaction génotype - milieu adaptés à la diversité des besoins et des contraintes des acteurs de la filière semences. Thèse de doctorat. INA P-G, Paris, France.

Leont'ev (1977). Activity and Consciousness. In Philosophy in the USSR, Problems of Dialectical Materialism (pp. 180-197). Moscow: Progress.

Meynard J.-M., \& Jeuffroy M.-H. (2006). Quel progrès génétique pour une agriculture durable ? In Quelles variétés et semences pour des agricultures paysannes durables? Les dossiers de l'Environnement, INRA, Paris, (30), pp. 15-25

Miettinen, R. (2006). The Sources of Novelty: A Cultural and Systemic View of Distributed Creativity. Creativity and Innovation Management, 15 (2), 173-181. 
Rabardel, P. (1995). Les hommes et les technologies. Approche cognitive des instruments contemporains. Paris: Armand Colin.

SAS $^{\circledR}$ System, Release 8.01.01, 1999-2000. SAS ${ }^{\circledR}$ Institute Inc., Cary, NC, USA.

Sebillotte, M. (1980). An analysis of yield elaboration in wheat. In Wheat technical monograph (pp. 25-32). Bâle: CIBA-GEIGY.

Tsoukias, A. (2006). De la théorie de la décision à l'aide à la décision. In D. Bouyssou, D. Dubois, M. Pirlot, \& H. Prade, Concepts et méthodes pour l'aide à la décision 1 : outils de modélisation. Paris: HermesLavoisier.

Virkkunen, J. (2006). Dilemmes dans la construction d'une capacité d'action partagée de transformation, @ ctivités, 3 (1), 19-42.

\section{RÉSUMÉ}

Les innovations variétales sont depuis toujours un élément clé de la production en agriculture. Evaluer les comportements de nouvelles variétés face à une diversité de milieux (sol, climat, manière de produire) est alors un enjeu important pour les acteurs, depuis ceux qui sélectionnent ces nouvelles variétés jusqu'à ceux qui les cultivent ou en utilisent les produits. Pour concevoir un outil qui aide les acteurs à réaliser cette évaluation, agronomes et ergonomes ont collaboré pour articuler trois dimensions dans le travail de conception: (i) la cristallisation dans l'outil d'un modèle de l'activité, (ii) la plasticité de l'outil, et (iii) le développement conjoint de l'outil et de l'activité. Pour produire des spécifications en relation avec ces trois dimensions, nous analysons respectivement, (i) les invariants du système d'activité de l'évaluation variétale, (ii) la diversité les actions conduites par les acteurs de l'évaluation, (iii) les contradictions qui apparaissent dans le système d'activité. Notre analyse valorise des travaux d'historiens et s'appuie surtout sur des entretiens conduits auprès de 21 acteurs de l'évaluation variétale. Elle nous permet de mettre en avant le rôle central joué par l'outil qu'est le réseau d'expérimentation et de d'étudier la façon dont les acteurs mettent à profit l'indétermination des outils de l'activité pour les constituer en instruments. Elle montre que l'objet de l'activité a été historiquement constitué autour de l'évaluation à la stabilité du comportement d'une variété et que cette dernière continue à orienter les actions des acteurs. Elle permet d'identifier 11 actions d'évaluation variétale différentes. Elle montre les contradictions qui émergent aujourd'hui au sein de l'objet compte tenu des nouveaux enjeux auxquels doivent faire face les acteurs. Elle débouche sur des spécifications pour un prototype d'outil suffisamment ouvert pour s'adapter à la diversité des actions et susceptible d'aider les acteurs à lever les contradictions identifiées.

\section{MoTS CLÉS}

Conception d'outils, instruments, système d'activité, agriculture.

\section{RESUMEN :}

Las innovaciones varietales han sido, desde siempre, un elemento clave de la producción en la agricultura. La evaluación de los comportamientos de las nuevas variedades frente a una diversidad de entornos (suelo, clima, forma de producir), es entonces un desafío importante para los actores, desde aquellos que seleccionan estas nuevas variedades hasta quienes las cultivan o utilizan los productos. Para diseñar una herramienta que ayude a los actores a realizar dicha evaluación, han colaborado agrónomos y ergónomos para articular tres dimensiones en el trabajo de concepción: (i) la cristalización en la herramienta de un modelo de la actividad (ii) la plasticidad de la herramienta, y (iii) el desarrollo conjunto de la herramienta y de la actividad. Para producir las especificaciones con relación a estas tres dimensiones, analizamos respectivamente, (i) las invariantes del sistema de actividad de la evaluación varietal, (ii) la diversidad de las acciones realizadas 
por los actores de la evaluación, (iii) las contradicciones que aparecen en el sistema de actividad. Nuestro análisis valoriza el trabajo de los historiadores $\mathrm{y}$, sobre todo, se apoya en las entrevistas realizadas a 21 actores de la evaluación varietal. Nos permite poner de relieve el rol central jugado por la herramienta que es la red de experimentación, así como estudiar la forma en que los actores aprovechan de la indeterminación de las herramientas de la actividad para convertirlas en instrumentos. El análisis muestra que el objeto de la actividad ha estado históricamente constituido alrededor de la evaluación de la estabilidad del comportamiento de una variedad, y que esta última continúa a orientar las acciones de los actores. Asimismo, permite identificar 11 acciones diferentes de evaluación varietal y muestra las contradicciones que emergen en torno del objeto, habida cuenta de los desafíos que deben enfrentar los actores. Finalmente, el análisis desemboca en especifaciones para un prototipo de herramienta suficientemente abierto para adaptarse a la diversidad de acciones y susceptible de ayudar a los actores a remontar las contracciones identificadas.

Palabras clave:

Diseño de herramientas, instrumentos, sistema de actividad, agricultura. 


\section{Appendix 1.}

The five main questions put to the interviewees.

1- Could you tell me what your role is in the company and what decisions you have to take?

2- Could you describe how those decisions are made and what information you use?

3- Could you specify what seem to you the most serious risks of error, and what you do to minimise them?

4- Could you describe the current system of cultivar field trials which you are in charge of or which you use?

5- Could you tell me how your methods of organisation, practices and systems have changed, and what factors were responsible for the changes? 


\section{Appendix 2}

Extract from a summary table transcribing the interviews. This extract describes the goals of the various actors, in their own words. The table shows the replies given by the interviewees, with a reference to the corresponding reply in the interview. The column headings give an initial summary of the replies.

\begin{tabular}{|c|c|c|c|c|c|c|c|}
\hline $\begin{array}{l}\text { Interview } \\
\text { code }\end{array}$ & $\begin{array}{l}\text { 1. Defining breeding } \\
\text { objectives }\end{array}$ & $\begin{array}{c}\text { 2. Breeding, } \\
\text { registering, selecting } \\
\text { cultivars }\end{array}$ & $\begin{array}{l}\text { 3. Positioning } \\
\text { cultivars }\end{array}$ & $\begin{array}{l}\text { 4. Determining } \\
\text { surface areas for } \\
\text { multiplication }\end{array}$ & $\begin{array}{l}\text { 5. Acquiring data } \\
\text { on cultivars }\end{array}$ & $\begin{array}{l}\text { 6. Drawing up } \\
\text { documents on } \\
\text { cultivars }\end{array}$ & $\begin{array}{l}\text { 7. Publici- } \\
\text { sing cultivars }\end{array}$ \\
\hline S1-1 & & $\begin{array}{l}\text { Submitting } 3 \text { to } 5 \\
\text { lineages a year for } \\
\text { registration }(93,477 \text {, } \\
497) \text {. Highest yield } \\
\text { potential possible } \\
\text { (177). We hardly do } \\
\text { any feed wheat now, } \\
\text { aiming for the ba- } \\
\text { king-strength wheat } \\
\text { niche (483) }\end{array}$ & $\begin{array}{l}\text { Determining the } \\
\text { geographical posi- } \\
\text { tion of registered } \\
\text { cultivars }(142,153)\end{array}$ & & $\begin{array}{l}\text { Acquiring info } \\
\text { on seed rates, } \\
\text { early or late, } \\
\text { wheat-on-wheat } \\
\text { performance }(233 \text {, } \\
249,587)\end{array}$ & $\begin{array}{l}\text { Publishing fact } \\
\text { sheets (248) }\end{array}$ & $\begin{array}{l}\text { In future: or- } \\
\text { ganise visits } \\
\text { to trial sites } \\
\text { (595) }\end{array}$ \\
\hline S2-1 & $\begin{array}{l}\text { Orienting breeding } \\
\text { criteria ( } 300 \mathrm{~s}) \text {. Must } \\
\text { anticipate developments } \\
\text { and acquire information } \\
\text { (288). Market demand } \\
\text { moving towards very } \\
\text { productive, high-quality } \\
\text { wheat (106). Changing } \\
\text { legal requirements, } \\
\text { moving towards more } \\
\text { rustic types (74) }\end{array}$ & $\begin{array}{l}\text { Choice of } 3 \text { cultivars } \\
\text { per year max to sub- } \\
\text { mit for registration } \\
\text { (136). Importance of } \\
\text { productivity criteria } \\
\text { ( } 74 \mathrm{~s}) \text {, protein content } \\
(30) \text {, quality }(80 \% \\
\text { of crossbreeds with } \\
\text { good baking potential } \\
\text { (78)), earliness ( } 25 \% \\
\text { of crossbreeds early, } \\
60 \% \text { in the northern } \\
\text { area }(96 \mathrm{~s})) \text {, resistan- } \\
\text { ce to alternativity and } \\
\text { lodging }(82,86 \mathrm{~s}) \text {. }\end{array}$ & $\begin{array}{l}\text { Seeking comple- } \\
\text { mentarity: targeting } \\
\text { cultivars by zone } \\
\text { and sowing date } \\
(82,184) \text {, once } \\
\text { crossbreeding has } \\
\text { been done ( } 86) \text {, } \\
\text { greater importance } \\
\text { to earliness /alterna- } \\
\text { tivity ( } 82) \text {. }\end{array}$ & & & & \\
\hline S2-2 & $\begin{array}{l}\text { Defining breeding targets } \\
\text { (6), designing program- } \\
\text { mes (4) and avoiding } \\
\text { drifting off course (2), } \\
\text { staying close to market } \\
\text { realities ( } 30) \text {. «We're not } \\
\text { trying to bring out good } \\
\text { varieties, we're trying } \\
\text { to bring out varieties } \\
\text { that sell.» }\end{array}$ & $\begin{array}{l}\text { Choosing cultivars } \\
\text { (176), criteria: } \\
\text { baking quality and } \\
\text { protein content (22). }\end{array}$ & $\begin{array}{l}\text { Positioning cultivars } \\
\text { geographically (176) }\end{array}$ & $\begin{array}{l}\text { Determining } \\
\text { surface areas for } \\
\text { multiplication } \\
(180)\end{array}$ & & & \\
\hline D3-2 & $\begin{array}{l}\text { Orienting targets of } \\
\text { breeding programmes } \\
\text { (189). Importance of } \\
\text { quality (52), response to } \\
\text { nitrogen rates, date and } \\
\text { density of sowing. In } \\
\text { past 5-6 years, decision } \\
\text { to work only with } \\
\text { baking-strength wheat } \\
\text { and good test weight } \\
\text { cultivars (95). }\end{array}$ & & $\begin{array}{l}\text { Changing info on } \\
\text { technical positioning } \\
\text { of cultivars with a } \\
\text { view to putting them } \\
\text { on the market (2). }\end{array}$ & $\begin{array}{l}\text { Contributing } \\
\text { to choice of } 1 \text { st } \\
\text { multiplications } \\
(237,241)\end{array}$ & $\begin{array}{l}\text { Acquiring cultiva- } \\
\text { tion techniques on } \\
\text { cultivars and the } \\
\text { means to add to } \\
\text { them (2) }\end{array}$ & $\begin{array}{l}\text { Ensuring tech- } \\
\text { nical support } \\
\text { throughout the } \\
\text { life cycle of a } \\
\text { cultivar (2) }\end{array}$ & $\begin{array}{l}\text { Turning the } \\
\text { info. into } \\
\text { commercial } \\
\text { arguments } \\
\text { to sell the } \\
\text { cultivars in- } \\
\text { ternally and } \\
\text { externally } \\
\text { (2) }\end{array}$ \\
\hline & & & & & & & \\
\hline
\end{tabular}

Subsequently, the goals mentioned were specifically refocused on the experimental tool, and the columns were regrouped into broad categories. In each category, the replies were distributed according to three criteria, which may correspond to increasing order of importance (high, average, low): this is the case with the goals but it is not systematic. Processing the information in this way resulted in summary tables similar to Table 2. 